\title{
Evaluating An Online Learning Programme from Students' Perspectives
}

\author{
Ayodele O. Ogunleye, University of Lagos, Nigeria
}

\begin{abstract}
Today, we are in an information age and the goal of education is to help teachers incorporate technology into the education curriculum This study was designed to evaluate the effectiveness of students' participation in a blended first-class online programme for 40 practicing teachers and administrators in one of the colleges of the University of London with respect to sex, age and occupation. The study employed the use of a questionnaire, which was divided into four parts viz: Learning environment, Personal factors, Pedagogical strategies and Learning process. The major findings of the study showed that sex and age are the major variables that contribute to successful online learning, while participants' occupations seem not to have any effect. Furthermore, online learning contributes more to the acquisition of the following skills with respect to age and sex: browsing and searching skills, information gathering skills, and library references searching skills. Online learning programs, however, do not generally contribute to arousing students' interest. The implications of the findings were further discussed.
\end{abstract}

\section{INTRODUCTION}

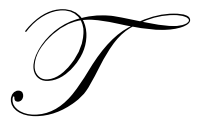

he advancement of Information and Communication Technology (ICT) has made a significant impact on education in recent years in terms of the ways and manner in which we conceive, see, work, think, learn and socialize. With regard to teaching and learning, especially in distance education where the learner and the teacher are separated in time and space, ICT in the form of a web-based learning environment has supported an array of instructional delivery media by utilizing the effective pedagogical strategies that involve the active participation of the learner in the construction of new knowledge. In addition, many of the features of web-based learning, such as the synchronous learning activities (e.g. computer conferencing and chats), asynchronous learning activities (e.g. e-mail), graphics, sound and video illustrations, and human interfaces, all provide for effective communication strategies and an enabling environment to enable teachers to develop the diverse types of learning materials. Information can now be acquired, processed, transported (i.e. communicated), stored and delivered timely and with desired form into a point where it is required.

Today, we are in an information age and the goal of education is to help teachers incorporate technology into the education curriculum. The Information age is driven by new technologies and new techniques through the widespread use of Information and Communication Technology revolution. With the advent of globalization, the overall objectives of education should not be seen anymore as simply to convey a known body of knowledge, but in addition, education should be able to enhance the quality of the learner to generate, assess, access and apply knowledge and information to solve societal and other complex problems. Educational institutions, therefore, are responding rapidly to these changes, especially to learners' demands for anytime and anywhere education by devoting substantial resources to the development of distance and online learning programmes instead of the traditional face-to-face learning. Face-to-face education is teaching and learning where a significant component requires the presence of both learner and tutor in the same physical space at the same time. Traditional distance education, on the other hand, can be used to describe teaching and learning situations where the significant components do not require the presence of both learner and tutor in the same place at the same time. The teaching in this type of learning environment is delivered using correspondence, books and other paper-based materials and supplemented by audio-visual materials, such as video, TV and radio. However, recent developments in technology and access have offered many universities such greater opportunities to enable them to improve this environment through increased communication interactivity among participants and incorporating collaborative pedagogical 
models, specifically through electronic networks and GroupWare.

The term e-learning is used synonymously with technology-based learning and covers a wide set of applications and processes which involve computer-based learning, web-based learning, virtual classrooms and collaboration. Online learning is also another term that constitutes just one part of technology-based learning. It describes learning via Internet, Intranet and extranet, which includes such activities as animations, simulations, audio and video sequence, peer and extranet groups, online mentoring, and links to materials on an intranet or the web. Today many courses are being developed that increasingly involve the use of online components, not only in distance education, but also at residential universities that primarily deliver courses through face-to-face lectures and seminars. These online and blended interactions need to be evaluated to ensure that they result in active learning.

At the Institute of Education, University of London, an online learning environment has been in existence based on first-class online course delivery and many courses now make use of one or more aspects of first-class, especially for in-service and training programmes of teachers or for various other purposes. First class makes use of print-based learning materials (supplemented with audio, and videos, CD-ROM), web-based technology and face-toface blended interaction, all designed for active student learning. Self-instruction with additional learning support to students, namely discussion board, chart, emails and hyperlinks to useful websites, are also provided. Moreover, the online environment has great potential for collaborative learning among participants who are separated in time and space.

This paper attempts to evaluate the effectiveness of students' participation in the blended first-class online learning programme.

\section{REVIEW OF LITERATURE}

Successful use of online communication in courses has been reported by a number of researchers. Many of these courses had either been delivered online or had incorporated a blended approach as an additional means of learner support in delivering the online courses. However, there are variations in the reported benefits of online learning.

Merron (1999), Anderson et. al. (2000) both reported that students performed better in their courses while Lake (1999) discovered that online learning can provide psychological support, reducing the feeling of isolation and drop-out rates. Lake (1999) further argued that online discussion encouraged introverts and students of non-western cultures - who are more reflective and tend not to respond so quickly in face-to-face discussion - to express their views.

Hollenbark (1998) found that learners have become more autonomous in online learning while McDonald and Garbriel (1998) believed that learners are now more critical in their thinking and more effective in knowledge synthesis (Borns, 1999). Depending on their motivation, some learners may only participate in activities that they consider more fruitful. For example, Lockwood (1995) reported that some learners actively sought ways to aid their performance on assignments and therefore, such learners may only participate in online discussion if it is linked to their assessment. According to Clark (2001), linking online discussion to grades would ensure a high participation rate.

A substantial body of literature that relates different forms of evaluation methodology and implementation also exists. Calder (1994), for example, provides a comprehensive presentation of evaluating programmes and organizational learning open and distance education and states that evaluation is used - or should be used - to enable institutions to operate as learning organizations (p. 19). Hence, evaluation should give an institution the opportunity to learn from its activities and improve its practices. In flexible delivery, students tend to take more responsibility for their own learning than do students in a traditional course. For this reason, evaluation of students' learning behaviour should centre on learning behaviour instead of teaching behaviour. Rowntree (1998) clearly describes this difference when he pointed out that there is less evidence to be gained from performance, hence the focus of evaluation shift from teaching to learning. 
Furthermore, any evaluation of flexible delivery should prioritize the student study experience over actual pass rate, even though both could be acknowledged as important. In other to measure student experiences, Chenng (1998) recommended that student questionnaires should address the following distinct areas:

1. Student development (student study habits, workload, their overall impression of the module)

2. $\quad$ Assessment (assessment task design, the level of feedback received)

3. Student perception of the learning materials (how well they facilitated learning, interest generated, difficulties they encounter, overall presentation of learning (materials)

4. Effectiveness of face-to-face contact (the organization, knowledge, facilitation skills of lecturer)

Oliver (2000) identified three roles of evaluation: 1) identification of the information needs of users, 2) the usability of the web-based portal site, and 3) the selection of materials.

Another alternative approach to evaluation might be to focus on the types of data that online systems are good at gathering. Phillips and Reynolds (1998), for example, combined web- based questionnaires, which allowed for immediate responses with system usage data, such as the time and frequency of page access.

Today, educators, teachers, researchers and students alike are well aware of the potential of web technology and may have adopted it for creating a new learning environment. Hence, we now have a huge repertoire of educational websites. One objective of this is the belief that certain unique features of the technology (e.g. its powerful information, manipulation tools and communication means) can substantially contribute to the teaching and learning process. For example, the information manipulation functions, such as generating, transmitting, storing, processing and retrieving information, are at the heart of educational transactions according to Mioduser, Bnachnifil, Lahav and Onan (2000). The communication functions (e-mail, group conferencing and Internet Relay Chat) enable students to communicate with experts and teachers, as well as to conduct collaborative work (Berge and Colling, 1995, Haraism, Hiltz Tehers and Turoff, 1995). Hittezt (1997) has equally pointed out that the web also serves as an instructional medium whereby numerous websites that provide digital educational activities and network-based courses for all levels and in a variety of subject areas have been developed.

Mioduser et. al. (2000) classified websites into four main dimensions:

1. The Descriptive Dimension: This dimension includes basic information organised in four categories regarding the location, creators, target population and relevant technical data of a site. The information is organized into four categories:

2. The Pedagogical Dimension: The variables in this dimension unveil the developers' stance regarding the type of instruction elicited by their site (e.g. target learning processes, instructional configuration and means, collaborative work, feedback and assessment). The variables in this dimension are organized into the ten major categories.

3. The Knowledge Dimension: This dimension relates to qualitative and structural issues concerning the sites knowledge and support for knowledge navigation. This dimension comprises the of four categorizes of variables.

4. The Communication Dimension: Networking, by definition, implies communication - people's interaction with knowledge, other people, or both. The fourth dimension of the taxonomy relates to communication features in four categories.

From their study of the characteristics of different websites as to the teaching and learning environment, they found that many educational websites are still predominantly text-based and do not yet exhibit evidence of current pedagogical approaches (e.g. use of inquiriy-based activities, application of constructivists' learning principles and use of alternative evaluation methods).

Hron and Friedrich (2003) reviewed web-based collaboration learning with respect to the social communication situation, message exchange, cognitive load and participation of the learners. From various research studies carried out by others, they pointed out: 
1. Computer-mediated communication in the only possibility for allowing locally distributed persons or groups to communicate, both synchronously and asynchronously. However, this leads to a social situation which deviates from familiar face-to-face situations.

2. The exchange of messages in web-based learning scenarios offers considerable advantages, such as mutual message exchange between situations that can take place at any time so that participants do not have to wait for explicit taking turns. Likewise, topics can be discussed temporarily in parallel and separated into subtopics, making structured discussions possible for larger groups.

3. Web-based collaborative learning makes great demands on its learners who must operate a complex technology, deal with an often complex subject matter, and communicate with other learners at the same time. The communication context alone can lead to difficulties, especially if the learners do not have prior experience with communication media. Further, web-based learning can result from the fact that interaction and collaboration between the group members does not casually occur, but rather has to be explicitly initiated and maintained by them.

4. Learners' active participation is necessary in web-based collaborative learning since learners must have to read messages, ask questions, make comments and give answers. Learners also have to decide when and how often they bring themselves into the learning process (e.g. once a week) and for how long they will take part, as well as which contributions they will need and answer.

Establishing social presence is another important aspect of effective online interaction and learning. As the online environment becomes more widely used for teaching courses and networking learners, the process of participants establishing social presence in an online learning environment is beginning to be explored. Social presence, as defined by Garrison (1997), is the degree to which participants are able to project themselves effectively within the medium. This is a growing area of focus for research as teachers and researchers find that for cognitive presence to be sustained, social presence in an online learning environment must first be established. Stacey (1999), in a study into online collaborative learning of students in an MBA program, found that interactive online group discussion was central to the learners' effective construction of new conceptual understandings. Thus, through the social context of group interaction, the collaborative groups developed a consensus of knowledge through communicating different perspectives, receiving feedback from other students and teachers, and discussing ideas until a final negotiation of understanding was reached.

According to Jonasen et. al. (1999) and Hughers and Hewson (1998), social interaction forms the foundation on which all levels of interactivity are dependent and is therefore critical in the building of a collaborative learning environment. McLoughlin (1999) believed that social exchanges have the potential to alleviate misunderstandings and misinterpretations that can occur through the lack of social cues and face-to-face interaction. The social communities that are created during the learning process can have impact on the nature of the learning activities and the learning outcomes. Geer and Barnes (2002) identified the various types of interactivity of technology-mediated instruction in the following hierarchical order:

$\begin{array}{ll}\text { 1. } & \text { Collaboration } \\ \text { 2. } & \text { Cooperation } \\ \text { 3. } & \text { Closed discussion } \\ \text { 4. } & \text { Moderated discussion } \\ \text { 5. } & \text { Topic focused discussion } \\ \text { 6. } & \text { General discussion } \\ \text { 7. } & \text { Social interaction }\end{array}$

Learning tasks is another important item of supporting net-based collaborative learning. Hence, it is necessary for one to choose suitable learning tasks that can foster motivation, interest and the active participation of the learners. Roblyer et al (1997) identified the following learning tasks that can measure up to these conditions:

1. Collaborative topic: related data recall or information search on the Internet with presentation and discussion of the results afterwards.

2. Parallel problem-solving where groups first work independently on the solution of a given problem and then exchange and discuss their solutions. 
3. Co-operative project work where a project is subdivided into sub-projects which are dealt by individual groups and integrated afterwards.

4. Electronic excursions to curricular important places on the Internet (e.g. cities, landscapes, excavation places, political, cultural, scientific institutions, etc) and e-mail communication with inhabitants of these places.

Schrum (2002) identified the following seven dimensions of students' success in online learning: 1) access to tools, 2) technology experience, 3) learning preferences, 4) study habits and skills, 5) goals and purposes, 6) lifestyle factors, and 7) personal traits and characteristics.

According to Kolb (1985), learner characteristics may also reflect many demographic attributes such as readiness, learning styles and motivation to learn. Differences in learning styles are as a result of such things as past life experiences and the demands of the present environment. Kolb (1985) further identified four learning styles: 1) the converger, 2) the diverger, 3) the assimilator, and 4) the accommodator. A converger uses abstract conceptualization and active experimentation, while the diverger works best in the presence of concrete experiences. The assimilator creates models for the task at hand, while for the accommodator, learning in best conceived as a process.

Birkey (1994) identified two of the learning styles; i.e. accommodator and converger, as very significant predictors for students choosing classes with high computer usage. This is because both of these learning styles have active experimentation as a common learning mode. On the other hand, Jonassen and Grabowski (1993) identified the two other learning styles; i.e. assimilators and divergers, as more thought intensive, imaginative and intuitive as they use sound logic as an approach to problem-solving. Divergers tend to be open-minded and assimilators deal well with systematic and scientific approaches. The various learning styles mentioned play very important roles in a learner's ability to create web pages.

\section{PURPOSE OF STUDY}

The study was designed to evaluate the effectiveness of students' participation in the blended first-class online programme with respect to sex, age and occupation. The study sought answers to the following research questions:

1. What are the various students' perspectives on the online course and which student support services constitute an adequate component of the course?

2. To what extent has the online course increased student competencies in the various skills associate with new technologies?

3. What resources do students perceive to be easily available for their use in their various places of work?

\section{POPULATION}

The students who served as the target audience for this evaluation were distance learners who enrolled in a one-month online programme at the Institute of Education, University of London. The students who enrolled in the programme were geographically distant from the university. The population of the student was 40.

\section{METHOD}

An online questionnaire was used to collect data for the evaluation. The questionnaire was divided into four sections. Section one required a general background of information from participants. Section two consisted of 20 items that requested students to evaluate the course programme, and they were subdivided into four major areas:

$\begin{array}{ll}\text { Learning environment: } & \text { items 1-5 } \\ \text { Personal factors: } & \text { items 6-10 } \\ \text { Pedagogical strategies: } & \text { items 11-15 } \\ \text { Learning process: } & \text { items 16-20 }\end{array}$ 
Section three of the questionnaire consisted of ten items and students were required to evaluate if the online course programme increased their competencies in the various skills associated with new technologies.

Finally, Section four of the questionnaire requested students to identify which of the resources available during their training could also be easily available for their use in their places of work. The content validity of the items of the questionnaire was established by a five-person expert team from three universities. After the review and based on the feedback, the necessary modifications were made to the instrument.

\section{RESULTS}

The means and standard deviations of student responses to Section two of the questionnaire are given in Table 1. The learning environment items have the highest mean of 3.17, which was recorded for item 4; i.e. the course content delivery and all the face-to-face interaction should have been done online. This is closely followed by item 20 with a mean of 2.64 (i.e. "in the future, I would have preferred to receive all of my course materials, including the CD ROMS, at the start of the course"). Students also believed that lecture rooms for face-to-face interactions should have been fully equipped with computers and Internet facilities (item 2 with a mean of 2.61). The least mean of 1.50 is for item 9 (i.e. "another objective of attending this course was to satisfy my professional and personal development"). This is closely preceded by item 6 with a mean of 1.64 (i.e. "the course activated my attention and aroused my interest"). The total means for the various categories are given in Table 2.

Table 1: Means and Standard Deviation of Student Responses

\begin{tabular}{|c|c|c|c|}
\hline & & Means & S.D. \\
\hline 1. & The course gave me access to enough teaching resources, library references and databases. & 2.11 & .785 \\
\hline 2. & $\begin{array}{l}\text { Lecture rooms for face-to-face interactions should have been fully equipped with computers } \\
\text { and internet facilities. }\end{array}$ & 2.61 & .837 \\
\hline 3 & There was enough academic and institutional support during the period of the course. & 2.25 & .649 \\
\hline 4. & $\begin{array}{l}\text { The course content delivery and all other face-to-face interactions should have been done on } \\
\text { time. }\end{array}$ & 3.17 & .517 \\
\hline 5. & The course tutor was quite active and knowledgeable. & 1.78 & .637 \\
\hline 6 & The course activated my attention and aroused my interest. & 1.64 & .542 \\
\hline 7 & The course is quite responsive to my learning needs. & 2.06 & .631 \\
\hline 8 & $\begin{array}{l}\text { One objective of attending this course was for a specific purpose (e.g. to start an online } \\
\text { programme in my work place). }\end{array}$ & 2.00 & .756 \\
\hline 9. & $\begin{array}{l}\text { Another objective of attending this course was to satisfy my professional and personal } \\
\text { development. }\end{array}$ & 1.50 & .507 \\
\hline 10. & $\begin{array}{l}\text { With some reservations, the course is easy for me to use and adapt in other similar } \\
\text { circumstances. }\end{array}$ & 2.08 & .691 \\
\hline 11. & The training objectives were well stated. & 2.11 & .622 \\
\hline 12. & Sufficient examples were provided in this course. & 2.06 & .531 \\
\hline 13. & The training programme had enough feedback mechanisms. & 2.08 & .500 \\
\hline 14. & $\begin{array}{l}\text { The face-to-face sessions were purposeful, useful and fostered collaborative and co-operative } \\
\text { learning. }\end{array}$ & 1.92 & .732 \\
\hline 15. & The training programme took cognizance of learners' pre-requisite knowledge and skills. & 2.39 & .645 \\
\hline 16. & $\begin{array}{l}\text { I sometimes seek help from my fellow students whenever I find it difficult to do the } \\
\text { recommended task. }\end{array}$ & 2.03 & .736 \\
\hline 17. & $\begin{array}{l}\text { I made good use of my previous knowledge and skills to enable me to relate to this online } \\
\text { course successfully. }\end{array}$ & 1.69 & .624 \\
\hline 18. & $\begin{array}{l}\text { To deepen my knowledge of the course, I always look for more examples and applications in } \\
\text { relevant literature/websites. }\end{array}$ & 2.14 & .723 \\
\hline 19. & $\begin{array}{l}\text { I manage my own time effectively and I only study when I want to do my assignments and } \\
\text { tasks. }\end{array}$ & 2.06 & .583 \\
\hline 20. & $\begin{array}{l}\text { In the future, I would have preferred to receive all of my course materials (including the CD- } \\
\text { ROMS) at the start of the course. }\end{array}$ & 2.64 & .798 \\
\hline
\end{tabular}


Table 2: Total Means of Categories of Quantitative Items

\begin{tabular}{|ll|c|}
\hline \multicolumn{1}{|c|}{ Categories } & Means \\
\hline $1 . \quad$ Learning environment & 2.26 \\
\hline $2 . \quad$ Personal factors & 1.85 \\
\hline 3. & Pedagogical strategies & 2.11 \\
\hline $4 . \quad$ Learning process & 2.11 \\
\hline
\end{tabular}

Table 3: Means and Standard Deviation of Student Response to Computing Skills Acquisition

\begin{tabular}{|l|l|c|c|}
\hline & & Mean & S.D \\
\hline 1. & Visual skills (i.e. ability to read fast on the Internet) & 3.28 & .913 \\
\hline 2. & Browsing and searching skills & 1.33 & .671 \\
\hline 3 & Information gathering skills & 3.14 & 930 \\
\hline 4. & Downloading skills & 3.36 & .867 \\
\hline 5 & Listening skills & 367 & .586 \\
\hline 6 & Bookmark skills & 3.25 & .906 \\
\hline 7 & Graphics creation skills & 3.86 & .351 \\
\hline 8. & Printing skills & 3.78 & .421 \\
\hline 9. & Database knowledge skills & 3.69 & .624 \\
\hline 10. & Library reference searching skills & 3.14 & .990 \\
\hline
\end{tabular}

Table 4: Means of Students Responses to Availability of Resources

\begin{tabular}{|l|l|c|c|}
\hline & \multicolumn{2}{|c|}{ Easy to Get (Means) } & Could get if I tried (S.D) \\
\hline 1. & Video camera & 1.78 & .721 \\
\hline 2. & Camera-tape or digital & & .654 \\
\hline 3 & Interactive whiteboards & 2.11 & .840 \\
\hline 4. & Blackboard & 1.9 & .849 \\
\hline 5. & Mobile phones with text and Internet access & 2.28 & .671 \\
\hline 6. & Network computers & 1.33 & .540 \\
\hline 7. & Internet access for learners' use & 1.22 & .604 \\
\hline 8. & Printing facilities & 1.35 & .840 \\
\hline 9. & Technical laboratory & 1.91 & .753 \\
\hline 10. & Digital TV & 2.05 & .723 \\
\hline 11. & Latest software for multimedia & 2.14 & .736 \\
\hline 12. & Telephone conferencing facilities & 2.17 & \\
\hline
\end{tabular}

Table 2 shows that the learning environment was quite good and the course tutor was quite active and knowledgeable. There was enough academic and institutional support and sufficient access to library resources.

Furthermore, the pedagogical strategies were equally purposeful, useful and foster collaborative learning. There was also enough feedback mechanism. The least in the categories are those related to personal factors which has to do with arousing interest, responsive to students learning needs, and easily adjustable to other learning situations.

The results of the means of students' responses to Section three of the questionnaire are given in Table 4. The total average means is 3.25; hence, means that are above the total average mean point could be regarded as negative (not contributing), while those below could be regarded as positive (contributing). The results, therefore, show that the blended online learning program contributed immensely to the following skills, such as the library references searching skills (means $=3.14$ ), information gathering skills (mean $=3.14$ ), browsing and searching skills (mean $=1.33$ ) and bookmark skills (mean = 3.25). However, the course did little to increase students' skills in graphic creation $($ mean $=3.86)$, printing skills $($ mean $=3.78)$, database knowledge skills $($ mean $=3.69)$, listening skills $($ means $=3.67)$, downloading skills $($ mean $=3.36)$, and visual skills $)$ mean $=3.28)$. 
Table 5: Results of $X^{2}$ Statistics of Student Responses for Sex, Age and Occupation Variables

\begin{tabular}{|c|c|c|c|c|c|c|}
\hline \multirow{2}{*}{ Items } & \multicolumn{2}{|c|}{ Sex } & \multicolumn{2}{|c|}{ Age } & \multicolumn{2}{|c|}{ Occupation } \\
\hline & $\mathbf{X}^{2}$ & $\begin{array}{c}\text { Sig. } \\
\text { Level }\end{array}$ & $\mathrm{X}^{2}$ & $\begin{array}{l}\text { Sig. } \\
\text { Level }\end{array}$ & $\mathbf{X}^{2}$ & Sg. level \\
\hline $\begin{array}{l}\text { The course gave me access to enough teaching } \\
\text { resources, library references and databases. }\end{array}$ & 9.427 & .151 & 4.196 & .242 & 4.779 & .199 \\
\hline $\begin{array}{l}\text { Lecture rooms for face-to-face interactions should } \\
\text { have been fully equipped with computers and } \\
\text { Internet facilities. }\end{array}$ & 11.767 & .067 & 3.000 & .392 & 2.811 & .422 \\
\hline $\begin{array}{l}\text { There was enough academic and institutional } \\
\text { support during the period of the course. }\end{array}$ & 11.529 & .066 & 2.366 & .500 & 4.990 & .173 \\
\hline $\begin{array}{l}\text { The course content delivery and all other face-to- } \\
\text { face interactions should have been done on time. }\end{array}$ & 6.393 & .172 & 6.923 & .031 & 1.199 & .549 \\
\hline $\begin{array}{l}\text { The course tutor was quite active and } \\
\text { knowledgeable. }\end{array}$ & 6.185 & .186 & .6000 & .741 & .385 & .825 \\
\hline $\begin{array}{l}\text { The course activated my attention and aroused my } \\
\text { interest. }\end{array}$ & 6.896 & .141 & 3.429 & .180 & 602 & .740 \\
\hline $\begin{array}{l}\text { The course is quite responsive to my learning } \\
\text { needs. }\end{array}$ & 3.327 & .505 & 4.950 & .094 & 1.674 & .433 \\
\hline $\begin{array}{l}\text { One objective of attending this course was for a } \\
\text { specific purpose. }\end{array}$ & 6.800 & .147 & 2.951 & .226 & 1.162 & .559 \\
\hline $\begin{array}{l}\text { Another objective of attending this course was to } \\
\text { satisfy my professional and personal development. }\end{array}$ & 1.418 & .492 & 2.500 & .034 & .120 & .729 \\
\hline $\begin{array}{l}\text { With some reservations, the course is easy for me to } \\
\text { use and adapt in other similar circumstances. }\end{array}$ & 13.641 & .024 & 2.745 & .433 & 4.098 & 251 \\
\hline The training objectives were well stated. & 16.427 & .012 & 4.206 & .432 & 5.246 & 1.55 \\
\hline Sufficient examples were provided in this course. & 8.475 & .076 & .577 & .749 & 1.380 & .502 \\
\hline $\begin{array}{l}\text { The training programme had enough feedback } \\
\text { mechanisms. }\end{array}$ & 4.495 & .343 & .917 & 632 & 1.324 & .516 \\
\hline $\begin{array}{l}\text { The face-to-face sessions were purposeful, useful } \\
\text { and fostered collaborative and co-operative } \\
\text { learning. }\end{array}$ & 6.156 & .189 & .274 & .672 & .568 & .753 \\
\hline $\begin{array}{l}\text { The training programme took cognizance of } \\
\text { learners' pre-requisite knowledge and skills. }\end{array}$ & 8.109 & .218 & 4.720 & .193 & 3.541 & .316 \\
\hline $\begin{array}{l}\text { I sometimes seek help from my fellow students } \\
\text { whenever I find it difficult to do the recommended } \\
\text { tasks. }\end{array}$ & 8.043 & .090 & 16.271 & .006 & 3.965 & .138 \\
\hline $\begin{array}{l}\text { I made good use of my previous knowledge and } \\
\text { skills to enable me to relate to this online course } \\
\text { successfully. }\end{array}$ & 1.367 & .496 & 4.444 & .168 & 3.084 & .214 \\
\hline $\begin{array}{l}\text { To deepen my knowledge of the course, I always } \\
\text { look for more examples and applications in relevant } \\
\text { literature/websites. }\end{array}$ & 5.030 & .505 & 4.565 & .207 & 3.682 & .641 \\
\hline $\begin{array}{l}\text { I manage my own time effectively and I only study } \\
\text { when I want to do my assignments and tasks. }\end{array}$ & 5.026 & 2.85 & 2.975 & .226 & 1.056 & .590 \\
\hline $\begin{array}{l}\text { In the future, I would have preferred to receive all } \\
\text { of my course materials (including the CD-ROMS) } \\
\text { at the start of the course. }\end{array}$ & .6 .054 & .417 & 170 & 982 & 3.787 & .285 \\
\hline
\end{tabular}


Table 6: Result of $\mathrm{X}^{2}$ Statistics by Sex, Age and Occupation for Skills Acquisition

\begin{tabular}{|l|c|c|c|c|c|c|}
\hline \multicolumn{1}{|c|}{ Types of Skills } & \multicolumn{2}{c|}{ Sex } & \multicolumn{2}{c|}{ Occupation } & \multicolumn{2}{c|}{ Age } \\
\hline & Mean & S.D & Mean & S.D & Mean & S.D \\
\hline $\begin{array}{l}\text { Visual skills (i.e. ability to read fast on the } \\
\text { Internet) }\end{array}$ & 2.260 & .520 & 3.884 & 274 & 1.995 & .920 \\
\hline Browsing and searching skills & & & & & \\
\hline Information gathering skills & 5.486 & .139 & 1.713 & 634 & 6.649 & .194 \\
\hline Downloading skills & 4.016 & .260 & 2.970 & .396 & 12.576 & .050 \\
\hline Listening skills & 1.531 & .676 & 2.813 & 421 & 3.984 & .679 \\
\hline Bookmark skills & 3.525 & .316 & 1.736 & .629 & 10.054 & .172 \\
\hline Graphics creation skills & .656 & .720 & 1.092 & .582 & 3.357 & .500 \\
\hline Printing skills & .653 & .419 & 1.856 & .173 & 2.666 & 2.79 \\
\hline Database knowledge skills & .550 & .458 & .080 & .777 & 2.197 & .333 \\
\hline Library reference searching skills & .695 & .705 & 6.696 & .035 & 7.714 & .163 \\
\hline
\end{tabular}

Table 7: Results of $\mathrm{X}^{2}$ Statistics for Sex, Age, and Occupation for Availability of Resources

\begin{tabular}{|l|c|c|c|c|c|c|}
\hline \multicolumn{1}{|c|}{ Types of Resources } & \multicolumn{2}{c|}{ Sex } & \multicolumn{2}{c|}{ Occupation } & \multicolumn{2}{c|}{ Age } \\
\hline & Means & S.D & Mean & S.D & Mean & S.D \\
\hline Video camera & .891 & 628 & 4.375 & 233 & 3.665 & .722 \\
\hline Camera-tape or digital & .460 & 794 & .268 & .875 & 8.188 & .055 \\
\hline Interactive whiteboards & 2.323 & .313 & .532 & .767 & 1.488 & .829 \\
\hline Blackboard & .272 & .873 & 3.021 & .221 & 5.685 & .224 \\
\hline Mobile phones with text and Internet access & 3.488 & .175 & 6.747 & .034 & 2.691 & .076 \\
\hline Network computers & .550 & 759 & 10.286 & .006 & 2.906 & .574 \\
\hline Internet access for learners' use & 5.803 & .053 & 4.275 & .118 & 5.360 & .252 \\
\hline Printing facilities & 2.914 & .233 & 1.650 & .436 & 2.695 & .252 \\
\hline Technical laboratory & 2.225 & .329 & 1.052 & .601 & 2.695 & .616 \\
\hline Digital TV & 3.259 & 196 & 2.852 & .240 & 5.436 & .245 \\
\hline Latest software for multimedia & .679 & .750 & .564 & 764 & 12.465 & .014 \\
\hline Telephone conferencing facilities & .333 & .647 & 1.533 & .465 & 8.230 & .084 \\
\hline
\end{tabular}

The result for section four of the questionnaire on availability of resources is given in Table 4. Resources like mobile phones with test and Internet access (mean $=2.28)$, telephone conferencing facilities $($ mean 2.17$)$, and the latest software for multimedia (mean $=2.14$ ) are easily available for use. However, resources, such as Internet access for learners' use $($ mean $=1.22)$, network computers (mean 1.33), and printing facilities $($ mean $=1.35)$ are not easily available for use in their various work. A $\mathrm{X}^{2}$ statistic was also computed for all three areas of the questionnaire. The results are tabulated in Tables 5, 6 and 7 for the sex, age and occupation variables. In Table 5, high significant differences were recorded for item $11\left(X^{2}=16.427\right)$, item $10\left(X^{2}=13.641\right)$, item $2\left(X^{2}=11.767\right)$, and item $3\left(X^{2}=11.529\right)$ for the sex variables; and for age, item $16\left(X^{2}=16.271\right)$, item $4\left(X^{2}=6.923\right)$, and item 7 $\left(X^{2}=4.950\right)$. For occupation, significant differences were recorded for item $11\left(X^{2}=5.246\right)$ and item $3\left(X^{2}=\right.$ 4.990). The results of Table 6 for skills acquisition equally show that high significant differences were recorded under sex for item $2\left(X^{2}=5.486\right)$, under age for item $3\left(X^{2}=12.576\right)$, and under occupation for item $9\left(X^{2}=6.696\right)$.

Finally, the results of Table 7 for availability of resources show that high significant differences were recorded for item $11\left(X^{2}=12.465\right)$ for age, for item $6\left(X^{2}=10.286\right)$ for occupation, and item $7(x 2=5.803)$ for sex.

\section{DISCUSSION OF RESULTS}

The analysis given in Tables 1-6 could be summarized as follows:

1. Sex and age are the major variables that contribute to successful online learning, while participants' occupations seem not to have any effect.

2. Online learning contributes more to the acquisition of the following skills with respect to age and sex: 
a. browsing and searching skills

b. information gathering skills

c. library reference searching skills

3. With respect to occupation, some participants already have acquired skills, such as database knowledge, before enrolling in the online programme.

4. Online learning does not contribute to the ability of learners to read fast on the Internet and also to their printing or graphic skills.

5. Online programmes do not generally contribute to arousing students' interests.

6. Online programmes contribute more to collaborative and cooperative learning among students.

7. Online programmes deepen students' knowledge as they always look for more examples and applications in relevant literature/websites.

8. Students generally experience difficulty with resources, such as Internet access, network computers and printing facilities, in their place of work. Hence, these could possibly retard their progress and interest.

9. Face-to-face interactions should be an important component of online course programmes as face-to-face sessions are regarded as purposeful, useful and foster collaborate and cooperative learning.

10. Lecture rooms for face-to-face interactions should, however, be fully equipped with network computers, Internet access and printing facilities.

\section{CONCLUSION}

In light of these results, one can therefore accept the fact that online course programmes contribute effectively to collaborative and cooperative learning and also serve to deepen students' knowledge of course content by creating examples and application in relevant literature/websites. However, one important conclusion from this study is that there is not a single right way for online course delivery. Although the development of online education is still in its infancy, the findings of this study provide the necessary guidance in designing instructions for online learning for students, as well as identifying certain constraints that can affect students' attitudes to online learning, such as availability of resources. The findings also show that much more still needs to be done to arouse interest in online course delivery. The implication of this is that evaluation in the context of online learning must involve the learner, the resources available to students, and how to arouse their interest.

\section{AUTHOR'S INFORMATION}

Dr. Ayodele .O. Ogunleye is a teacher and science educator by profession. He is currently a Senior Lecturer in Science Education at the Faculty of Education, University of Lagos, Nigeria. He has a passion for teaching and research especially in physics education. He obtained M.Sc in Theoretical Physics from Friendship University, Moscow; M. Ed in Science Education from Chelsea College of Science and Technology, University of London; M. $\mathrm{Sc}$ in Computing and IT from University of Luton, Luton, U.K, and Ph.D. in Science Education from the University of Lagos, Lagos, Nigeria. In addition, he earned a Diploma in Science Education from Chelsea College of Science and Technology, University of London.

\section{REFERENCES}

1. Calder, J. (1994) Programme Evaluation and Quality (London, Kogan Degree).

2. Cheung, D. (1998) Develing a student evaluation instrument for distance testing Distance Education 19, (1), pp 23-42

3. Garrison, D. R (1997) Computer Conferencing and distance education: Cognitive and Social presence issues. In The New Learning environment: A global perfective, Proceedings of the ICDE World conference, Pennsylvania State University.

4. Geer, Ruth \& Bannes, A. (2002) Teaching and learning through technology mediated Interaction in Watson, D \& Andersen, J. (eds) Networking the Learner Kluwer Academic Publishers. London.

5. $\quad$ Generucher, K (1998 December 21) MBA programs online Infoworld 20 pp 71-72.

6. Gibbs, W. J (1998) Implementing online learning environment Journal Infoworld of Computers in Higher Education, 10 (1) pp, 16-37. 
7. Hughes, C. as Hewson. L. (1998) Online Interactions: Developing a neglected aspect of the virtual classroom. Educational Technology vol. July-August, pp. 48-55.

8. Jonaseen D. H., Peck K, L. \& Wilson, B. G. (1999) Learning with Technology: A constructivist Perspective, Merrill, Upper Saddle River, New Jersey.

9. Mcloughlia, C. (1999) Culturally responsive technology use: developing an online community of learners. British Journal of Educational Technology, 30 (3) pp, 231-243.

10. Roblyer, M. D., Edwards J. \& Havriluk, M. A (1997) Intergrating Educational Technology into Teaching Merrill/Prentive Hall, Upper Saddle River NJ.

11. Rowntree, D. (1998) Assessing the quality of materials-based teaching and learning. Open Learning, 13 (2) pp. 12-22.

12. Schrum, L (1998) Online education: A study of emerging pedagogy. In Adult learning and the internet, B. Gahoon (eds); Hershey, PA, Idea Groups Publishing, pp. 91-106.

13. Staney, E. (1999) Collaborative learning in an online environment Canadian journal of Distance education 14, 2 pp. 14-33.

14. Stancey, E. (2002) Social Presence Online. In Networking learners at a distance. In Networking the learner, D. Watsonas \& J. Andersen (eds). Boston: Kluwe Academic Publishers. 
NOTES 